Михайло Орда, кандидат технічних наук, старший науковий співробітник Національний університет оборони України імені Івана Черняховського, м. Київ ORCID ID 0000-0003-0374-3881

Михайло Черненок, Національний університет оборони України імені Івана Черняховського, м. Київ ORCID ID 0000-0001-5376-6606

DOI: $10.33099 / 2617-1775 / 2020-02 / 222-231$

\title{
НОРМАТИВНО-ПРАВОВЕ ЗАБЕЗПЕЧЕННЯ ОЦНЮВАННЯ РЕЗУЛЬТАТІВ ОСВІТИ ЗА ПІДСУМКАМИ СЛУЖБОВОЇ ДІЯЛЬНОСТІ ВИПУСКНИКІВ ВВНЗ
}

Досліджено питання нормативно-правового забезпечення оиінювання результатів освіти за підсумками службової діяльності випускників ВВНЗ.

Ключові слова: нормативно-правовий акт; система інформачійного забезпечення військової освіти; вищий військовий навчальний заклад; професійний стандарт; компетентність; оцінювання; службова діяльність; випускник.

Постановка проблеми. Забезпечення якості освіти як системної категорії потребує практичного впровадження принципово нових підходів в управлінні освітою. Традиційні підходи до управління освітніми, педагогічними системами, де перевага надається функції періодичного контролю, виявляються не здатними до оперативного, комплексного та прогнозованого реагування на зміни, що відбуваються як у внутрішньому освітньому середовищі, так і навколо, не сприяють сталому та прогнозованому розвитку системи підготовки військових фахівців. Важливою задачею на теперішній час стає створення принципово нової системи, яка б дозволяла здійснювати гнучке управління процесом підготовки фахівців на основі системи супровідного оцінювання, аналізу, коригування та прогнозування.

Основними показниками якості підготовки військових фахівців $є$ рівень сформованості у них певних компетентностей, їх відповідність вимогам стандарту вищої військової освіти за певною спеціальністю та професійного стандарту за визначеними у ВВНЗ спеціалізаціями.

Створення цілісної системи освітнього (педагогічного) оцінювання дозволяє постійно знати стан, проблеми навчання, своєчасно на них реагувати, прогнозувати перспективи розвитку освіти, досліджувати закономірності забезпечення якості освіти, освітньої діяльності, оцінювати ефективність прийнятих управлінських рішень, здійснювати підготовку, перепідготовку та ротацію керівних кадрів і науково-педагогічних працівників.

Останні десятиріччя характеризують об’єднанням зусиль різних країн у розробленні єдиних підходів до оцінки результатів навчання і проведенні міжнародних порівняльних досліджень, які дають цінну інформацію про стан освіти, дають можливість порівнювати підготовку фахівців за міжнародними 
стандартами, здійснювати моніторинг якості освіти. Незалежні експертні організації проводять зовнішнє оцінювання, розроблення критеріальної бази, контрольно-вимірювальних матеріалів, процедур оцінювання, складання рейтингів освітніх закладів, підготовку експертів і т. п. Обов'язковою рисою систем зовнішньої оцінки якості освіти є їхня відкритість і прозорість, доступність результатів для зацікавлених осіб і організацій. Надійна інформація про якість освіти стає у сучасному світі виробничим ресурсом, а в основу успішних стратегій управління якістю навчання закладають три базових елементи: широкий погляд на освітні результати і поєднання різних методів оцінки освітніх досягнень, якість освітніх програм і ефективність освітнього процесу.

Аналіз останніх досліджень і публікацій Організаційно-педагогічні засади експертного оцінювання навчально-виховної діяльності загально-освітніх шкіл успішно розробляють О. С. Боднар, Н. В. Стребкова та ін. В. Л. Погрібна і В. В. Мальцев визначають набір принципів, на основі яких будується система критеріїв оцінювання. В полі зору таких дослідників, як С. Альохіна, Б. Вінницький, О. Кузьмін, М. Лендьєл, О. Мазурик, Ю. Ратейчак, І. Санжаровський, знаходяться проблеми моніторингу та оцінювання освітніх програм. Значний внесок в оцінювання якості військової освіти внесено науковою школою на чолі 3 професором Зельницьким А.M. [1-4], який дав подальший розвиток впровадженню методів кваліметрії.

Мета статті - дослідження проблематики та нормативно-правових актів 3 питань оцінювання результатів освіти і підготовки випускників ВВНЗ та ВНП ЗВО за підсумками службової діяльності.

Методи дослідження - аналіз нормативно-правових актів, принципи військово-технічного аналізу, системного аналізу, методи порівняння та аналогії, узагальнення й систематизації теоретичних знань; а також методи ідеалізації та абстрагування.

Виклад основного матеріалу. В контексті переходу на перспективну освітню модель, що визначається компетентнісним спрямуванням та спільною відповідальністю стейкхолдерів за якість вищої освіти, набувають особливої уваги питання оцінювання результатів освіти і підготовки випускників ВВНЗ та ВНП ЗВО за підсумками службової діяльності.

Питання оцінювання результатів навчання випускників ВВНЗ та ВНП ЗВО за підсумками їх службової діяльності опосередковано розглянуто в таких нормативних документах:

Концепція військової кадрової політики у Збройних Силах України на період до 2020 року, затверджена наказом Міністерства оборони України від 26.06.2017 № 342 [5];

Методичні рекомендації з порядку організації і проведення атестування військовослужбовців Збройних Силах України, затверджені директором Департаменту кадрової політики Міністерства оборони України від 19.04.2017 № 328 (зі змінами від 12.10.2018 № 226/4907) [6].

Методичні рекомендації щодо підготовки відгуку на випускника ВВНЗ 
Збройних Сил України (військового навчального підрозділу закладу вищої освіти, далі - ВНП 3ВО)[7].

Крім зазначених документів питання оцінювання службової діяльності випускників ВВНЗ частково висвітлено в Положенні про особливості організації освітньої діяльності у ВВНЗ Міністерства оборони України та ВНП ЗВО, затвердженому наказом Міністерства оборони України від 09.01.2020 № 4 [8].

У даному нормативному документі введено поняття "професійний стандарт" - це вимоги до компетентностей військового фахівця, що слугують основою для формування професійних кваліфікацій. Із врахуванням відповідних професійних стандартів формується зміст військової освіти в межах відповідної освітньої програми.

Професійний стандарт розробляється органом військового управління, який $\epsilon$ замовником на підготовку військових фахівців за участю представників ВВНЗ (ВНП 3ВО). Він погоджується директором Департаменту військової освіти, науки, соціальної та гуманітарної політики Міністерства оборони України та затверджується відповідним керівником органу військового управління, який $є$ замовником.

Він входить до переліку основних документів ВВНЗ (ВНП ЗВО), які регламентують організацію та забезпечення освітньої діяльності. Тобто саме завдяки цьому нормативному документу урегульовується зв'язок між замовниками на підготовку військових фахівців та ВВНЗ.

У п. 1.4 розділу ІІІ Організація освітнього процесу у ВВНЗ та ВНП ЗВО зазначено, що "вибіркова частина індивідуального навчального плану забезпечує виконання поглибленої підготовки за спеціальністю (спеціалізацією) та визначає характер майбутньої діяльності випускника і формується з переліку навчальних дисциплін або блоків навчальних дисциплін циклів загальної та професійної підготовки".

Крім того, у п. 1.6 цього ж розділу Положення зазначено, що “зміни, які вносяться після затвердження робочої програми навчальної дисципліни 3 метою оперативного впровадження в освітній процес вимог замовників щодо підвищення якості підготовки офіцерських та сержантських (старшинських) кадрів у ВВНЗ (ВНП ЗВО), у тому числі щодо посилення практичної складової підготовки військових фахівців, впровадження досвіду бойових дій, результатів наукових досліджень, удосконалення змісту навчання та методики викладання навчальної дисципліни, нових елементів МТБ, оновленої навчально-методичної літератури тощо, обговорюються на засіданні кафедр та затверджуються керівником (начальником) структурного навчального підрозділу, до складу якого входить кафедра."

Саме цей інструментарій дозволяє коригувати освітній процес ВВН3 3 урахуванням відгуків на випускників, надісланих з військ.

Концепція військової кадрової політики у ЗС України на період до 2020 року, затверджена наказом Міністерства оборони України від 26.06.2017 № 342, $є$ орієнтиром для вдосконалення нормативно-правової бази, організаційної, наукової, освітньої та інших видів діяльності органів військового управління у 
сфері військової кадрової політики.

У ній зазначено, що на сьогодні ще спостерігається той факт, що “командирами військових частин допускається необ'єктивна оцінка службової діяльності підлеглих військовослужбовців".

У певній мірі це пов'язано 3 тим, що “існують проблеми 3 розміщенням випускників оперативно-тактичного та оперативно-стратегічного рівнів на посади відповідно до набутого рівня військової освіти та спеціальності”.

3 огляду на викладене вище, необхідно удосконалити роботу щодо:

забезпечення розподілу випускників ВВНЗ (ВНП ЗВО), ад’юнктур, докторантур відповідно до отриманого рівня освіти та набутої спеціальності;

оптимального розподілу на посади випускників ВВНЗ (ВНП ЗВО) у війська (сили) як основного джерела їх комплектування;

здійснення індивідуального планування кар'єри військовослужбовців відповідно до типових алгоритмів управління кар'єрою, визначених вимог до посад та результатів їх службової діяльності;

подальшого удосконалення системи атестування військовослужбовців як у мирний час, так і на особливий період.

Удосконалення підготовки кадрів і системи військової освіти дозволить підвищити якість теоретичної та практичної підготовленості особового складу до виконання обов'язків за посадами призначення. Буде завершено створення системи підготовки сержантського i старшинського складу. Безперервна підготовка кадрів, що органічно поєднує військову освіту, перепідготовку та підвищення кваліфікації, створить умови для постійного професійного розвитку особового складу, забезпечить його кар'єрне зростання протягом всієї служби та підтримання високої бойової готовності військ (сил).

3 метою вдосконалення системи військової освіти та підготовки кадрів для 3С України необхідно завершити приведення нормативно-правових актів Міністерства оборони України у галузі військової освіти до вимог законодавства України з урахуванням досвіду проведення Антитерористичної операції (операції Об'єднаних сил), подальше законодавче і нормативне врегулювання питань підготовки військових фахівців.

У Методичних рекомендаціях з порядку організації і проведення атестування військовослужбовців ЗС України, затверджених директором Департаменту кадрової політики Міністерства оборони України від 19.04.2017 № 328 (зі змінами від 12.10.2018 № 226/4907), визначено такі критерії діяльності військовослужбовця:

рівень теоретичних знань;

рівень практичних умінь та навичок;

виконання посадових обов'язків;

рівень сформованості ідейних та моральних якостей;

ефективність управлінської діяльності (зокрема, рівень володіння навичками управління та організаторськими навичками; рівень прояву лідерських якостей та прагнення до самовдосконалення; індивідуальна оцінка виконання нормативів бойової підготовки тощо); 
професійний розвиток підлеглих (а саме рівень вимогливості до підлеглих);

штабна культура (культура роботи з документами), що передбачає якість складання та оформлення службових документів, уміння письмового викладення матеріалу, усного мовлення; а також рівень опанування суміжною спеціальністю (посадою);

уміння організовувати та проводити заняття (зокрема, якість організації та проведення занять, методична підготовленість тощо);

зовнішній вигляд та стройова виправка;

рівень фізичної підготовленості.

Атестація на присвоєння первинного військового звання офіцерського складу (далі - атестація) відображає:

для випускників ВВНЗ (ВНП ЗВО), які готуються для проходження військової служби на посадах осіб офіцерського складу - рівень підготовленості і придатності випускника, відповідності його професійно- важливих якостей вимогам військової спеціальності, готовність випускника до виконання посадових обов'язків на посадах офіцерського складу.

Для випускників ВВН3, які готуються для проходження військової служби на посадах осіб офіцерського складу, атестація складається на останньому курсі навчання не пізніше ніж за три місяці до закінчення підготовки. В особливий період у разі дострокового випуску атестування випускників до присвоєння первинного військового звання офіцерського складу проводиться безпосередньо перед їх державною атестацією. Вона складається прямими начальниками від начальника курсу, йому рівного i вище та затверджується начальником військового навчального закладу.

На сьогодні питання підготовки відгуку на випускника ВВНЗ найбільше висвітлено в Методичних рекомендаціях з підготовки відгуку на випускника вищого військового навчального закладу ЗС України (ВНП ЗВО), затверджені Міністром оборони України 02.11.2012 [7] та рекомендовані Департаментом військової освіти і науки Міністерства оборони України. Вони призначені для командирів (начальників) військових частин (підрозділів), а також для керівного складу та науково-педагогічних (педагогічних) працівників ВВНЗ (ВНП ЗВО). Рекомендації спрямовано на надання методичної допомоги командирам (начальникам) щодо оцінювання результатів службової діяльності випускників та підготовки обгрунтованих письмових відгуків на них. Вони також $є$ корисними для проведення аналізу у ВВНЗ (ВНП ЗВО) рівня сформованості у випускників визначених компетентностей i професійно важливих якостей та результатів виконання ними посадових обов'язків 3 метою удосконалення навчальновиховного процесу, покращення якості підготовки військових фахівців.

На думку розробників, основним показником якості підготовки військового фахівця - випускника ВВНЗ (ВНП ЗВО) є сформованість у нього відповідних компетентностей, що характеризуються ступенем здатності і готовності до застосування ним знань, навичок, умінь та особистісних якостей у ході виконання визначених службово-бойових функцій.

3-поміж основних компетентностей автори визначили такі: соціально- 
особистісні; загальнопрофесійні; спеціалізовано-професійні. Кожна 3 них містить певні професійно важливі якості, прояв яких визначається сформованістю відповідних умінь і навичок, що становить основу відгуку на випускника.

Отже, в основу запропонованого оцінювання покладено компетентністний підхід.

Проте слід зауважити, що дані Методичні рекомендації носять рекомендаційний характер, тому на сьогодні використовують різні підходи до оцінювання службової діяльності випускників ВВНЗ (ВНП ЗВО), а отже, і форми відгуків з військ суттєво різняться.

На даний час діє Указ Президента України про "Положення про проходження громадянами України військової служби у ЗС України” [9].

До цього указу наказом Міністра оборони України від 10.04.2009 № 170 введена в дію "Інструкція про організацію виконання Положення про проходження громадянами України військової служби у Збройних Силах України". В цій інструкції зазначено наступне:

Періодичне оцінювання проводиться між щорічними оцінюваннями.

7.6. Періодичне оцінювання проводиться:

випускників військових навчальних закладів після року військової служби, через рік після закінчення підготовки за денною формою навчання;

7.7. За підсумками щорічного оцінювання складається оцінна картка військовослужбовця. Результати незалежного, комплексного і періодичного оцінювання вносяться відповідно до розділів $6,7,8$ оцінної картки військовослужбовця (додаток 15). На посадових осіб, які безпосередньо підпорядковані Міністру оборони України, оцінна картка не складається.

За результатами періодичного оцінювання складається службова характеристика, а в окремих випадках, визначених пунктом 7.6 цього розділу, атестація на присвоєння військового звання офіцерського складу, нагородний лист, відгук на випускника військового навчального закладу після року служби.

7.8. Атестація на присвоєння військового звання офіцерського складу, оцінна картка i скорочена оцінна картка (далі - оцінні картки) та службова характеристика військовослужбовця складаються в порядку, визначеному Міністерством оборони України.

Відгук на випускника військового навчального закладу складається за формою, визначеною Генеральним штабом ЗС України.

Директивою Генерального штабу ЗС України від 06.03.2014 № ДГШ-6 “Про затвердження Табеля термінових донесень ЗС України 3 кадрових питань та підготовки військових фахівців", а саме розділом 5 (3 питань підготовки військових фахівців) пунктом 5.6 присвоєно номер форми донесення (відомостей) 5.6 OC та у додатку визначена сама форма Відгуку на випускника після року служби у військах.

Але директивою Генерального штабу ЗС України від 05.10.2018 № Д-15 “Про затвердження Змін до Табеля термінових донесень ЗС України з кадрових питань та підготовки військових фахівців", внесено зміни у директиву Генерального штабу ЗС України від 06.03.2014 № ДГШ-6, а саме: 
розділ 5 (з питань підготовки військових фахівців) повністю змінений окрім пунктів 5.1, 5.12-5.20, тобто замість форм донесень (відомостей) визначених пунктами 5.2-5.11 введено нові. Відгук на випускника після року служби у військах (форма 5.6 ОС від 06.03.2014 № ДГШ-6) був замінений на інший документ, у той же час нова форма Відгуку на випускника після року служби у військах у директиві від 05.10.2018 № Д-15 не введена.

Висновки. Відгук на випускника після року служби у військах розглядається як чи не єдиний інструмент зворотного зв’язку з питань оцінювання результатів навчання випускників та відповідного корегування освітнього процесу, решта форм зворотного зв'язку в кращому випадку просто згадуються в нормативно-правових та керівних документах але не мають юридично закріплених формалізованих алгоритмів використання.

Наказ Міністра оборони України від 10.04.2009 № 170 визначає, що Відгук на випускника військового навчального закладу після року служби у військах складається за формою, визначеною Генеральним штабом Збройних Сил України. До введення в дію директиви від 05.10.2018 № Д-15 така форма визначалась директивою 06.03.2014 № ДГШ-6 пунктом 5.6 номер форми донесення (відомостей) 5.6 ОС (але директива від 05.10.2018 № Д-15 цю форму скасувала). Тобто на даний час документ Генерального штабу ЗС України який легітимізує та визначає форму Відгуку на випускника військового навчального закладу після року служби у військах відсутній.

Єдиний документ, яким користуються на даний час щодо оцінювання випускників за підсумками їх службової діяльності у військах (силах) $\epsilon$ Методичні рекомендації з підготовки відгуку на випускника вищого військового навчального закладу 3С України (ВНП ЗВО), які затверджені Міністром оборони України 09.11.2012. Але даний документ має лише рекомендаційний характер, а тому не є обов'язковими до виконання, що не сприяє системності при аналізі (повноті охоплення всіх випускників) та стандартизації цих описів (оцінюванню випускників на єдиних засадах), а також майже унеможливлює процес автоматизації цього аналізу.

Напрями подальших досліджень Напрямом подальших досліджень $є$ створення системи оцінювання результатів освіти і підготовки за підсумками службової діяльності випускників, налагодження взаємного зв'язку замовниквиконавець на підставі створення єдиної бази даних та відповідного програмного забезпечення, у тому числі на платформі дистанційного навчання.

\section{ЛІТЕРАТУРА}

1. Зельницький А.М. Якість вищої військової освіти як результат функціонування педагогічної системи ВВНЗ / А. М. Зельницький // Військова освіта. - 2017. - № 1. - С. 62-69. Режим доступу: http://nbuv.gov.ua/UJRN/vios_2017_1_11.

2. Псьол С.В. Аналіз професійної діяльності випускників вищого навчального закладу як інструмент зворотного зв'язку в системі підготовки фахівця / С. В. Псьол // Збірник наукових праць Національної академії Державної прикордонної служби України. Серія: Педагогічні та психологічні науки. - 2013. - № 1. - С. 205-214. - Режим доступу: http://nbuv.gov.ua/UJRN/znpnapv_ppn_2013_1_24. 
3. Зельницький А.М. Відгук з військ на випускника ВВНЗ, ВНП ВНЗ у системі управління якістю підготовки військових фахівців / А. М. Зельницький // Вісник Національного університету оборони України. - 2011. - Вип. 1. - С. 14-25. - Режим доступу: http://nbuv.gov.ua/UJRN/Vnaou_2011_1_5.

4. Устименко О., Капосльоз Г., Полторак М. Ретроспективний аналіз підготовки фахівців для Збройних Сил України в системі вищої військової освіти крізь призму антитерористичної операції / О. Устименко, Г. Капосльоз, М. Полторак // Військова освіта. - 2019. - № 1. - С. 214 226. - Режим доступу: http://nbuv.gov.ua/UJRN/vios_2019_1_22.

5. Наказ Міністерства оборони України від 26.06.2017 № 342 Концепція військової кадрової політики у Збройних Силах України на період до 2020 року [Електронний ресурс] Режим доступу: https://www.mil.gov.ua/ministry/normativno-pravova-baza/nakazi-ministra-oboroniukraini.

6. Методичні рекомендації 3 порядку організації i проведення атестування військовослужбовців Збройних Сил України, затверджені директором Департаменту кадрової політики Міністерства оборони України від 19.04.2017 № 328 (зі змінами від 12.10.2018 № 226/4907).

7. Методичні рекомендації щодо підготовки відгуку на випускника вищого військового навчальною закладу Збройних Сил України (військового навчального підрозділу вищого навчального закладу) Толок І.В., Черних Ю.О., Приходько Ю.І., Зельницький А.М., Водолазський В.О., Поліщук Т.В.

8. Наказ Міністерства оборони України від 09.01.2020 року № 4 "Про затвердження Положення про особливості організації освітньої діяльності у вищих військових навчальних закладах Міністерства оборони України та військових навчальних підрозділах закладів вищої освіти, затвердженим наказом Міністерства оборони України” [Електронний ресурс] - Режим доступу : https://www.mil.gov.ua/ministry/normativno-pravova-baza/nakazi-ministra-oboroni-ukraini.

9. Указ Президента України від 10.12.2008 № 1153/2008 “Про Положення про проходження громадянами України військової служби у Збройних Силах України” (зі змінами).

\section{REFERENCES}

1. Zelnytskyi A.M. Yakist vyshchoi viiskovoi osvity yak rezultat funktsionuvannia pedahohichnoi systemy VVNZ / A. M. Zelnytskyi // Viiskova osvita. - 2017. - № 1. - S. 62-69. Rezhym dostupu: http://nbuv.gov.ua/UJRN/vios_2017_1_11.

2. Psol S.V. Analiz profesiinoi diialnosti vypusknykiv vyshchoho navchalnoho zakladu yak instrument zvorotnoho zviazku v systemi pidhotovky fakhivtsia / S. V. Psol // Zbirnyk naukovykh prats Natsionalnoi akademii Derzhavnoi prykordonnoi sluzhby Ukrainy. Seriia : Pedahohichni ta psykholohichni nauky. - 2013. - № 1. - S. 205-214. - Rezhym dostupu: http://nbuv.gov.ua/UJRN/znpnapv_ppn_2013_1_24.

3. Zelnytskyi A.M. Vidhuk z viisk na vypusknyka VVNZ, VNP VNZ u systemi upravlinnia yakistiu pidhotovky viiskovykh fakhivtsiv / A. M. Zelnytskyi // Visnyk Natsionalnoho universytetu oborony Ukrainy. - 2011. - Vyp. 1. - S. 14-25. - Rezhym dostupu: http://nbuv.gov.ua/UJRN/Vnaou_2011_1_5.

4. Ustymenko O., Kaposloz H., Poltorak M. Retrospektyvnyi analiz pidhotovky fakhivtsiv dlia Zbroinykh Syl Ukrainy v systemi vyshchoi viiskovoi osvity kriz pryzmu antyterorystychnoi operatsii / O. Ustymenko, H. Kaposloz, M. Poltorak // Viiskova osvita. - 2019. - № 1. - S. 214-226. - Rezhym dostupu: http://nbuv.gov.ua/UJRN/vios_2019_1_22.

5. Nakaz Ministerstva oborony Ukrainy vid 26.06.2017 № 342 Kontseptsiia viiskovoi kadrovoi polityky u Zbroinykh Sylakh Ukrainy na period do 2020 roku [Elektronnyi resurs] - Rezhym dostupu : https://www.mil.gov.ua/ministry/normativno-pravova-baza/nakazi-ministra-oboroni-ukraini.

6. Metodychni rekomendatsii $\mathrm{z}$ poriadku orhanizatsii $\mathrm{i}$ provedennia atestuvannia viiskovosluzhbovtsiv Zbroinykh Syl Ukrainy, zatverdzheni dyrektorom Departamentu kadrovoi polityky Ministerstva oborony Ukrainy vid 19.04.2017 № 328 (zi zminamy vid 12.10.2018 № 226/4907). 
7. Metodychni rekomendatsii shchodo pidhotovky vidhuku na vypusknyka vyshchoho viiskovoho navchalnoiu zakladu Zbroinykh Syl Ukrainy (viiskovoho navchalnoho pidrozdilu vyshchoho navchalnoho zakladu) Tolok I.V., Chernykh Yu.O., Prykhodko Yu.I., Zelnytskyi A.M., Vodolazskyi V.O., Polishchuk T.V.

8. Nakaz Ministerstva oborony Ukrainy vid 09.01.2020 roku № 4 "Pro zatverdzhennia Polozhennia pro osoblyvosti orhanizatsii osvitnoi diialnosti u vyshchykh viiskovykh navchalnykh zakladakh Ministerstva oborony Ukrainy ta viiskovykh navchalnykh pidrozdilakh zakladiv vyshchoi osvity, zatverdzhenym nakazom Ministerstva oborony Ukrainy" [Elektronnyi resurs] - Rezhym dostupu : https://www.mil.gov.ua/ministry/normativno-pravova-baza/nakazi-ministra-oboroni-ukraini.

9. Ukaz Prezydenta Ukrainy vid 10.12.2008 № 1153/2008 “Pro Polozhennia pro prokhodzhennia hromadianamy Ukrainy viiskovoi sluzhby u Zbroinykh Sylakh Ukrainy” (zi zminamy).

\title{
PЕЗЮМЕ
}

\author{
Михаил Орда, \\ кандидат технических наук, старший научный сотрудник \\ Национальный университет обороны Украины \\ имени Ивана Черняховского \\ Михаил Черненок, \\ Национальный университет обороны Украины \\ имени Ивана Черняховского
}

\section{Нормативно-правовое обеспечение оценивания результатов образования по итогам служебной деятельности выпускников ВВУЗ-ов}

Исследован вопрос нормативно-правового обеспечения оценки результатов образования по итогам служебной деятельности выпускников вуза.

Ключевые слова: нормативно-правовой акт; система информачионного обеспечения военного образования; высшее военное учебное заведение; профессиональный стандарт; компетентность; оценки; служебная деятельность; выпускник.

\section{SUMMARY}

Mikhailo Orda,
PhD (technical sciences), Senior Researcher
National Defence University of Ukraine
named after Ivan Chernyahovskyi
Mikhailo Chernenok,
National Defence University of Ukraine
named after Ivan Chernyahovskyi

\section{Regulatory support for the assessment of educational results based on the results of the service activities of graduates of high military school}

The article explores the issue of regulatory support for assessing educational results based on the results of the service activities of university graduates.

Introduction. Ensuring the quality of education as a systemic category requires the practical implementation of fundamentally new approaches in education management. Traditional approaches to the management of educational and pedagogical systems, where preference is given to the function of periodic control, are not able to respond quickly, comprehensively and predictably to changes in the internal educational environment and around, do not contribute to sustainable and predictable development of military training specialists. An important task at present is the creation of a fundamentally new system that would allow flexible management of the training process based on a system of accompanying assessment, analysis, adjustment and forecasting. 
Purpose. Research of issues and regulations on the evaluation of educational results and training of graduates of high military school based on the results of official activity.

Methods. analysis of normative legal acts, principles of military-technical analysis, system analysis, methods of comparison and analogy, generalization and systematization of theoretical knowledge; as well as methods of idealization and abstraction.

Result. The response to the graduate after a year of service in the army is considered as almost the only feedback tool for evaluating the results of graduate training and appropriate adjustment of the educational process, other forms of feedback at best are simply mentioned in regulations and guidelines but not have legally established formalized algorithms of use.

Originality. The main problematic issues regarding the regulatory support for the assessment of educational results based on the results of the service activities of graduates of high military school of the Armed Forces are:

- the place of ensuring the quality of education as a systemic category requires the practical implementation of fundamentally new approaches in education management;

- there is no clear understanding of the stages of issues and regulations on the evaluation of educational results and training of graduates of high military school based on the results of official activity;

- there are no criteria for the relevant content and tools for the practical implementation in military education.

Addressing these issues is important and relevant given the improvement of the career development system of officers (service), achieving positive results in military education, forming a team of military professionals.

Conclusion. The direction of further research is to create a system for evaluating the results of education and training based on the results of professional activities of graduates, establishing mutual relations between the customer and the contractor on the basis of creating a single database and software, including on the distance learning platform.

Key words: normative legal act; information support system of military education; higher military educational institution; professional standard; competence; assessments; official activity; graduate. 